\title{
PENDIDIKAN HUKUM MELALUI PENGUATAN NILAI BUDAYA LOKAL DALAM RANGKA MENCEGAH PENYEBARAN COVID-19 DI LOKASI WISATA
}

\author{
Oheo K. Haris, Handrawan Handrawan, Ahmad Firman Tarta \\ Fakultas Hukum Universitas Halu Oleo, Kendari \\ oheokh@gmail.com
}

\begin{abstract}
Abstrak
Penelitian ini ditujukan menganalisis kepatuhan terhadap kebijakan protokol kesehatan seperti menjaga jarak dan menggunakan masker, khususnya selama berada di lokasi wisata wisata Pantai Toronipa menimbulkan kekahawatiran akan berpotensi menjadi klaster baru penyebaran Corona Virus Disease 2019 (COVID-19) di lokasi wisata. Selanjutnya, penelitian ini menilai upaya-upaya yang harus dilakukan guna menumbuhkan dan meningkatkan kesadaran masyarakat atas kebijakan protokol kesehatan. Metode penelitian yang digunakan yaitu empiris. Penelitian ini menghasilkan bahwa pendidikan hukum melalui penguatan nilai-nilai budaya lokal dalam rangka mencegah penyebaran COVID-19 di lokasi wisata Pantai Toronipa. Kondisi ini dapat dilakukan dengan cara penguatan regulasi berbasis komunitas integrasi dan relasi, penguatan kelembagaan secara integratif baik antara pemerintah, masyarakat maupun swasta sebagai upaya mitigasi bencana COVID-19. Selain itu, cara utama untuk mengantisipasi kondisi tersebut adalah dengan miningkatkan kecerdasan dan pemahaman hukum tentang kebijakan protokol kesehatan melalui pendidikan hukum khususnya pendidikan hukum melalui penguatan nilai-nilai budaya. Penguatan kelembagaan yang berbasis kearifan lokal dalam bentuk kesiapsiagaan, sistem peringatan dini tentang peningkatan COVID-19 di sektor pariwisata.
\end{abstract}

Kata kunci: COVID-19; Nilai Budaya Lokal; Pendidikan Hukum

\section{LEGAL EDUCATION THROUGH STRENGTHENING VALUES LOCAL CULTURE TO PREVENT THE SPREAD COVID-19 AT BEACH TOURISM LOCATION}

\begin{abstract}
This research aimed at analyzing of obedience of health protocol policies such as physical distancing and wearing masks, especially while at the Toronipa beach tourist location, raises concerns that it will potentially become a new cluster of COVID-19 spread at tourist sites and in the end, it might spread in the community around the Toronipa beach tourist location. Subsequently, this paper also assessing of efforts that ought to be implemented community awareness toward health protocol policies. The research method used is empirical research. This study is revealing that legal education by means of local culture values in order to prevent COVID-19 spreading in the tourism location of Toronipa. In such condition, it has to be strengthened the regulation by relation-based community-based regulations, strengthening institutional integration both between the government, the community and the private sector as an effort to mitigate the COVID-19 disaster. Besides, the main way to anticipate these conditions is to increase intelligence and legal understanding of health protocol policies through legal education, especially legal education through strengthening cultural values. Legal education through strengthening local cultural values in order to prevent the spread of COVID-19 at the Toronipa beach tourist location can be done by strengthening integration and
\end{abstract}


p-ISSN : 2541-2345, e-ISSN : 2580-8842

strengthening local wisdom-based institutions in the form of preparedness, early warning systems regarding the increase in covid in the tourism sector

Keywords: COVID-19; Local Cultural Value; Legal Education

\section{PENDAHULUAN}

\section{A. Latar Belakang}

Kepadatan pengujung di tempat wisata semakin hari semakin ramai. Meskipun telah memasuki era adaptasi kebiasaan baru (new normal), masih banyak wisatawan yang tidak mematuhi kebijakan protokol kesehatan seperti menjaga jarak dan menggunakan masker, khususnya selama berada di lokasi wisata. Sementara, penyebaran pandemi COVID-19 di Indonesia secara signifikan terus mengalami peningkatan. Hal ini berdasarkan data yang dikeluarkan oleh Gugus Tugas Nasional Percepatan dan Penanganan COVID19 pada hari Kamis tanggal 30 Agustus 2021 tambahan kasus baru yaitu 5.436 sehingga total positif COVID-19 di tanah air sudah mencapai 4.079.267 kasus. Melihat perkembangan penyebaran pandemi COVID-19 yang senantiasa mengancam kesehatan bahkan jiwa seseorang, tentu ini akan menjadi kekhawatiran tersendiri bagi masyarakat khususnya masyarakat yang hidup di lokasi wisata.

Penelitian sebelumnya membahas permasalahan apa saja yang terjadi pada pendidikan di masa pandemi COVID-19 dan memberikan solusi yang tepat untuk permasalahan yang ada pada pembelajaran daring agar pendidikan di Indonesia dapat terus berkembang meskipun di masa pandemi COVID- 19 saat ini. ${ }^{1}$ Begitu pula penelitian lainnya membahasa tentang bagaimana sebenarnya peran orang tua dalam mendampingi putra-putrinya saat terjadi pandemi COVID-19 termasuk di antaranya saat mendampingi anak belajar dari rumah. ${ }^{2}$ Sedangkan penelitian lainnya adalah mengetahui dan menganalisis penegakan hukum terhadap pelanggaran protokol kesehatan pada masa pandemi COVID-19 di Kota Ambon. Untuk mengetahui dan menganalisis penerapan sanksi terhadap pelanggaran protokol kesehatan yang dilakukan mayarakat pada masa pandemi COVID-19 di Kota Ambon. ${ }^{3}$ Kelebihan beberapa tulisan terdahulu adalah kepedulian dan perhatian khusus terhadap penangan COVI-19 beserta beberapa solusi-solusinya. Sebaliknya kelemahan

\footnotetext{
1 Irinna Aulia Nafrin and Hudaidah, "Perkembangan Pendidikan Indonesia Di Masa Pandemi Covid-19," Edukatif: Jurnal Ilmu Pendidikan 3, no. 2 (2021): 458.

${ }^{2}$ Fitri Andriani Euis Kurniati, Dina Kusumanita Nur Alfaeni, "Analisis Peran Orang Tua Dalam Mendampingi Anak Di Masa Pandemi Covid-19,” Jurnal Obsesi : Jurnal Pendidikan Anak Usia Dini 5, no. 1 (2021): 421.

${ }^{3}$ Iqbal Taufik Sherly Adam, Reimon Supusepa, Jacob Hattu, "Penegakan Hukum Terhadap Pelanggaran Protokol Kesehatan Yang Dilakukan Masyarakat Pada Masa Pandemi Covid-19 Di Kota Ambon," SASI 27, no. 2 (2021): 230-46.
} 
penelitian sebelumnya adalah bervariasi antara lain latar belakang cara penanganan yang mempunyai pengaruh kuat terhadap penyebaran COVID-19, misalkan di beberapa tempat yang memiliki karakter tersendiri. Dengan demikian, penanganan dan penyelesaian terhadap penularan COVID-19 ini sangat beragam. Akan tetapi penelitian ini membahas tentang kepatuhan masyarakat berdasarkan nila-nilai dan budaya kearifan lokal khususnya yang berada di lokasi tempat wisata pantai Toronipa.

Gambar 1.1. Berita Pelanggaran Kebijakan Protokol Kesehatan Mitra di Sektor Pariwisata

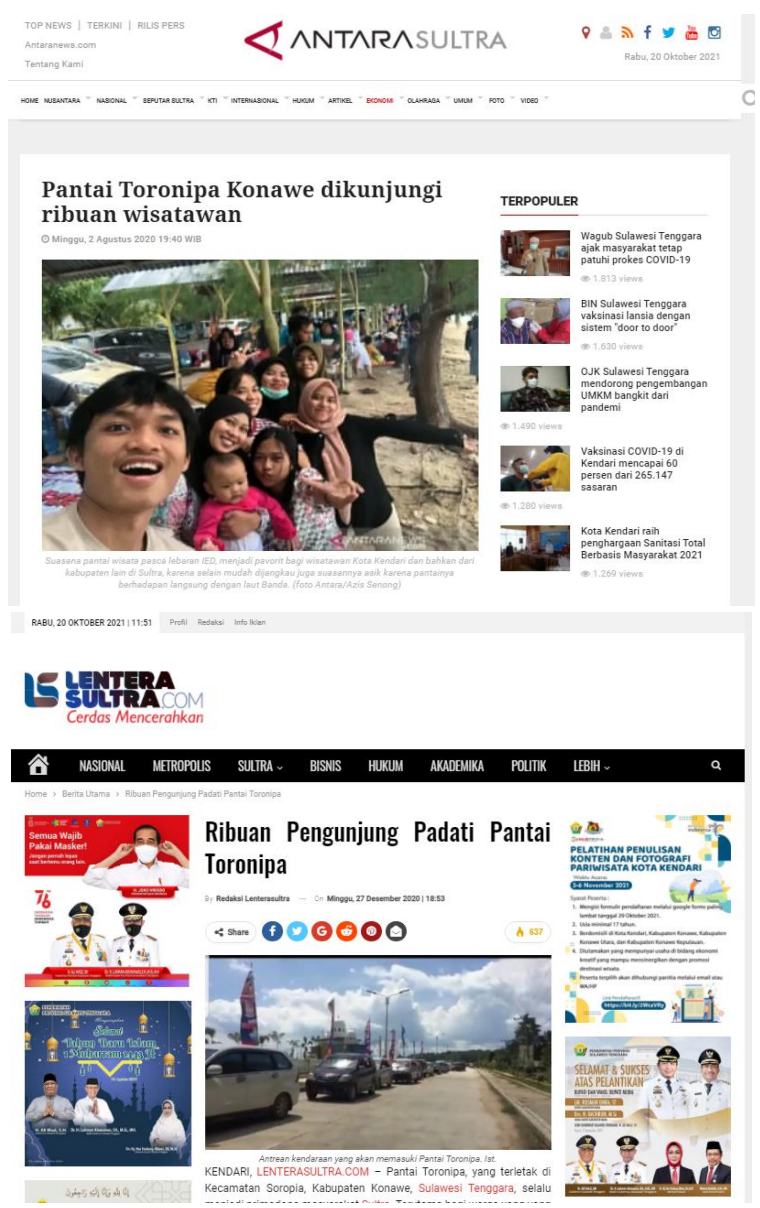

Sumber: Antaranews.com/LENTERASULTRA.COM

Penyebaran COVID-19 semakin meluas khususnya di lokasi wisata kelurahan Toronipa. Kondisi ini juga menjadi kekhawatiran masyarakat setempat. Melihat banyaknya kerumunan pengunjung di lokasi wisata Pantai Toronipa yang tidak memperhatikan kebijakan protokol kesehatan, dikhawatirkan akan berpotensi menjadi klaster baru penyebaran COVID-19 di lokasi wisata dan pada akhirnya akan menyebar di lingkungan masyarakat sekitar lokasi wisata Pantai Toronipa. Hal ini dapat dilihat pada Gambar 1.1, 
menunjukkan masih banyaknya pengujung wisata Pantai Toronipa yang tidak mematuhi kebijakan protokol kesehatan, misalnya menjaga jarak dan menggunakan masker. Kepatuhan atas kebijakan protokol kesehatan dilakukan hanya pada saat pengunjung hendak memasuki pintu masuk wisata Pantai Toronipa. Setelah berada di dalam lokasi pantai pengunjung sudah tidak lagi mengindahkan dan mematuhi kebijakan protokol kesehatan sebagaimana yang diberlakukan oleh pengelola wisata Pantai Toronipa. ${ }^{4}$

Berangkat dari kondisi tersebut, maka perlu adanya upaya yang harus dilakukan guna menumbuhkan dan meningkatkan kesadaran atas kebijakan protokol kesehatan oleh pengunjung maupun masyarakat setempat guna mencegah penyebaran COVID-19 di lokasi wisata. Jalan utama untuk mengantisipasi kondisi tersebut adalah dengan meningkatkan kecerdasan dan pemahaman hukum tentang kebijakan protokol kesehatan melalui pendidikan hukum khususnya pendidikan hukum melalui penguatan nilai-nilai budaya. Secara konseptual Pendidikan hukum merupakan pendidikan dalam upaya untuk mewujudkan kesadaran hukum. Sementara kesadaran hukum merupakan kesadaran tentang apa yang seyogyanya yang harus dilakukan atau perbuatan atau yang seyogyanya tidak dilakukan atau perbuat terutama terhadap orang lain serta kesadaran akan kewajiban masing-masing terhadap orang lain. ${ }^{5}$ Dengan demikian, diharapkan pendidikan hukum berbasis penguatan teknologi informasi dan budaya ini, akan memberikan pemahaman dan pengetahuan tentang berbagai kebijakan hukum tentang protokol kesehatan bagi pengunjung dan masyarakat setempat, khususnya tentang pengetahuan dan kesadaran hukum terkait dengan apa yang seharusnya dilakukan dan apa yang tidak boleh dilakukan selama berada di lokasi wisata melalui penguatan nilai-nilai budaya lokal.

Pendidikan hukum melalui penguatan nilai-nilai budaya lokal dalam rangka pencegahan penyebaran COVID-19 disektor pariwisata yang dimaksud adalah pemberian pemahaman dan pengetahuan masyarakat di lokasi wisata Pantai Toronipa sebagai ujung tombak dalam pelaksanaan kebijakan protokol kesehatan berbasis nilai-nilai budaya lokal di situasi pandemi COVID-19 di sektor pariwisata. Langkah ini dipilih sebagai solusi menghadapi banyaknya pengunjung dan masyarakat ketika berada di lokasi wisata Pantai Toronipa tidak mengindahkan kebijakan protokol kesehatan, seperti menjaga jarak dan memakai masker. Dengan demikian melalui pendidikan hukum melalui penguatan nilai-nilai budaya lokal ini dapat dilakukan dalam bentuk narasi-

\footnotetext{
4 Abdul Azis Senong, "Pantai Toronipa Konawe Dikunjungi Ribuan Wisatawan," Antara Sultra, 2020; Redaksi Lenterasultra, "Ribuan Pengunjung Padati Pantai Toronipa," Lentera Sultra, 2020.

5 Sudikno Mertokusumo, Meningkatkan Kesadaran Hukum Masyarakat, 1st ed. (Yogyakarta: Liberty, 1981), 13.
} 
narasi budaya lokal yang berisi pesan-pesan bahaya dan perlunya penanggulangan penyebaran COVID-19 di lokasi wisata Pantai Toronipa dalam rangka mengatasi permasalahan yang dihadapi oleh mitra.

Keberadaan penelitian sebelumnya telah membahas latar belakang yang berbeda-beda dalam penanganan terhadap penyebaran COVID-19. Kelebihan penelitian sebelumnya adalah terletak pada proses pembelajaran online selama masa COVID-19. Dalam hal ini peran guru dituntut untuk dapat berinovasi dalam menyampaikan materi pembelajaran. ${ }^{6}$ Guru dapat memanfaatkan platform yang ada untuk menunjang pembelajaran. Pembelajaran yang dilakukan secara daring tidak menjadi alasan untuk kita untuk tidak mendapatkan pendidikan. Kelebihan lain dari artikel ini terkait COVID-19 adalah peran orang tua yang muncul selama pandemi COVID-19 adalah sebagai pembimbing, pendidik, penjaga, pengembang dan pengawas. secara spesifik menunjukkan bahwa peran orang tua adalah menjaga dan memastikan anak untuk menerapkan hidup bersih dan sehat, mendampingi anak dalam mengerjakan tugas sekolah, melakukan kegiatan bersama selama di rumah, menciptakan lingkungan yang nyaman untuk anak, menjalin komunikasi yang intens dengan anak, bermain bersama anak, menjadi role model bagi anak, memberikan pengawasan pada anggota keluarga, menafkahi memberikan edukasi, memelihara nilai keagamaan, melakukan variasi dan inovasi kegiatan di rumah. ${ }^{7}$

Kelebihan lainnya adalah penegakan hukum terhadap pelanggaran protokol kesehatan pada masa pandemi COVID-19 di Kota Ambon dilaksanakan berdasarkan peraturan perundang-undangan, dengan melakukan Pembatasan Kegiatan Masyarakat (PKM), Pembatasan Sosial Berskala Besar (PSBB) sebagai bentuk penegakan hukum terhadap pelanggaran protokol kesehatan pada masa pandemi COVID-19 di Kota Ambon melalui sosialisasisosialisasi dalam pencegahan penyebaran virus COVID-19 dan Pembatasan Sosial Berskala Besar (PSBB) dengan menerapkan sanksi terhadap pelanggar. ${ }^{8}$

Sebaliknya, kelemahan-kelemahan penelitian terdahulu adalah terdapat dalam masing-masing latar belakang antara lain faktor-faktor yang menghambat dalam hal memutus mata rantai penyebaran COVID-19, kurangnya sarana dan prasarana, ketiadaan komunikasi antar pemegang kebijakan (decision maker) dan masyarakat (stakeholders). Hal ini dapat

\footnotetext{
${ }^{6}$ Opict, Nafrin and Hudaidah, "Perkembangan Pendidikan Indonesia Di Masa Pandemi Covid19."

7 Opcit, Euis Kurniati, Dina Kusumanita Nur Alfaeni, “Analisis Peran Orang Tua Dalam Mendampingi Anak Di Masa Pandemi Covid-19."

8 Opcit, Sherly Adam, Reimon Supusepa, Jacob Hattu, "Penegakan Hukum Terhadap Pelanggaran Protokol Kesehatan Yang Dilakukan Masyarakat Pada Masa Pandemi Covid-19 Di Kota Ambon."
} 
dimaklumi bahwa mengakhiri penyebaran COVID-19 sangat membutuhkan partisipasi semua pihak, mengelaborasi semua upaya, menyesuaikan semua aturan satu dengan lainnya, dan menegakkan peraturan perundang-undangan.

Selanjutnya, melalui kegiatan pelatihan dan talkshow. Dengan melakukan dua kegiatan tersebut diharapkan dapat menghasilkan output yang dapat menyelesaikan masalah yang dihadapi oleh mitra sejak dini khususnya dalam menanggulangi penyebaran pandemi COVID-19 di sektor pariwisata khususnya di lokasi wisata Pantai Toronipa. Berbagai permasalahan mitra tersebut di atas menjadi persoalan umum yang saat ini sedang melanda masyarakat Indonesia. Masalah ini menjadi sangat urgen karena jika tidak segera dicegah maka akan menimbulkan peningkatan dan akan menjadi klaster baru penyebaran pandemi COVID-19. Maka dari itu, perlu melakukan sosialisasi, penguatan dan pendidikan hukum yang berbasis nilai-nilai budaya lokal serta melakukan pengawasan secara ketat sebagai upaya pencegahan penyebaran COVID-19.

Melalui program pengabdian kemitraan ini akan melahirkan masyarakat peduli wisata, yang mampu mengedukasi pengunjung maupun masyarakat lainnya yang berada di sekitar lokasi wisata untuk dapat menjadi pelopor lahirnya budaya patuh protokol kesehatan di sektor pariwisata khususnya di lokasi wisata Pantai Toronipa. Berdasarkan hal tersebut, maka kegiatan pengabdian ini sangat penting untuk dilakukan. Selanjutnya sebagai bentuk tindak lanjut dari kegiatan ini, maka akan dibentuk gerakan masyarakat peduli wisata di situasi pandemi COVID-19 di Kelurahan Toronipa. Di mana melalui gerakan inilah yang akan menyebarkan pesan-pesan positif yang diperoleh dalam pendidikan hukum kebijakan protokol kesehatan dalam pencegahan penyebaran pandemi COVID-19 di sektor pariwisata, khususnya dalam bentuk narasi-narasi budaya lokal.

\section{B. Permasalahan}

Berikut rincian permasalahan masyarakat Kelurahan Toronipa sebagai wadah peningkatan kesadaran hukum kebijakan protokol kesehatan di sektor pariwisata adalah:

1. Bagaimana kesadaran hukum terkait pelaksanaan kebijakan protokol kesehatan di sektor pariwisata khususnya di lokasi wisata Pantai Toronipa?

2. Bagaimana model sosialisasi hukum tentang sanksi pelanggaran protokol kesehatan dalam pendekatan budaya lokal disektor pariwisata khususnya di lokasi wisata Pantai Toronipa?

3. Bagaimaan pemanfaatan dan penguatan nilai-nilai budaya lokal yang berbasis narasi budaya dalam rangka pencegahan penyebaran COVID-19 di sektor pariwisata khususnya di lokasi wisata Pantai Toronipa? 
4. Bagaimana upaya pendekatan Kolaborasi antara Penguatan pendidikan hukum dan budaya dalam pencegahan penyebaran COVID-19 disektor pariwisata khususnya di lokasi wisata Pantai Toronipa?

\section{Metode Penelitian}

Metode penelitian hukum empiris ini pada dasarnya merupakan penggabungan antara pendekatan hukum dengan adanya penambahan berbagai unsur empiris. ${ }^{9}$ Metode penelitian hukum empiris mengenai implementasi ketentuan hukum normatif (undang-undang) dalam aksinya pada setiap peristiwa hukum tertentu yang terjadi dalam suatu masyarakat. Teknik Pengumpulan bahan hukum dilakukan dengan 2 cara yakni teknik pengumpulan bahan hukum primer yang meliputi, pengumpulan bahan melalui wawancara dan bahan hukum sekunder yang meliputi observasi di wilayah Pantai Toronipa.

\section{HASIL DAN PEMBAHASAN}

\section{A. Perkembangan Rezim Pengaturan Hukum Berbasis Budaya Lokal di Situasi Pandemi COVID-19 di Sektor Pariwisata di Pantai Toronipa}

Saat ini, Indonesia sedang berperang dan berjuang melawan penyebaran dan penularan Corona Virus Disease 2019 (COVID-19) di tanah air. Dalam rangka menangani penyebaran Corona Virus Disease 2019 (COVID-19) di Indonesia, pemerintah telah membentuk beberapa peraturan perundangundangan di antaranya, Peraturan Pemerintah Pengganti Undang-Undang Nomor 1 Tahun 2020 tentang Kebijakan Keuangan Negara dan Stabilitas Sistem Keuangan untuk Penanganan Pandemi Corona Virus Disease 2019 (COVID-19) dan/atau dalam Rangka Menghadapi Ancaman Yang Membahayakan Perekonomian Nasional dan/atau Stabilitas Sistem Keuangan, Peraturan Pemerintah Nomor 21 Tahun 2020 tentang Pembatasan Sosial Berskala Besar dalam Rangka Percepatan Penanganan Corona Virus Disease 2019 (COVID-19) dan Keputusan Presiden Nomor 11 Tahun 2020 tentang Penetapan Kedaruratan Kesehatan Masyarakat Corona Virus Disease 2019 (COVID-19).

Tidak berhenti di situ saja, mengingat makin bertambahnya pasien COVID-19 di Tanah Air, Pemerintah Indonesia kemudian mengambil langkahlangkah strategis dalam rangka penanggulangan COVID-19 di tanah air. Salah satu langkah yang diambil oleh Presiden Joko Widodo saat itu adalah menetapkan COVID-19 sebagai wabah yaitu 4 Februari Tahun 2020, yang mana hal tersebut dituangkan lewat Keputusan Menteri Kesehatan Republik Indonesia Nomor HK.01.07/MENKES/104/2020 tentang Penetapan Infeksi

\footnotetext{
9 Irwansyah and Ahsan Yunus (Editor), Penelitian Hukum, Pilihan Metode \& Praktik Penulisan Artikel (Yogyakarta, Indonesia: Mirra Buana Media, 2020)., Yogyakarta, p.184.
} 
Novel Coronavirus (Infeksi 2019-nCoV) sebagai Penyakit yang Dapat Menimbulkan Wabah dan Upaya Penanggulangannya.

Untuk menangani penyebaran COVID-19 lebih jauh dan dalam rangka menjamin kepastian hukum, memperkuat upaya dan meningkatkan efektivitas pencegahan dan pengendalian Corona Virus Disease 2019 (COVID-19) di seluruh daerah, maka pemerintah Indonesia mengeluarkan Instruksi Presiden Republik Indonesia Nomor 6 Tahun 2020 tentang Peningkatan Disiplin dan Penegakan Hukum Protokol Kesehatan dalam Pencegahan dan Pengendalian Corona Virus Disease 2019 yang kemudian di teruskan dengan dikeluarkan Instruksi Menteri Dalam Negeri Nomor 4 Tahun 2020 tentang Pedoman Teknis Penyusunan Peraturan Daerah dalam Rangka Penerapan Disiplin dan Penegakan Hukum Protokol Kesehatan sebagai Upaya Pencegahan dan Pengendalian Corona Virus Disease 2019 di Daerah.

Hal ini pula ditindaklanjuti oleh Pemerintah Provinsi Sulawesi Tenggara dan Pemerintah Kabupaten Konawe. Di mana Pemerintah Provinsi Sulawesi Tenggara terkait Instruksi Presiden tersebut ditindak lanjuti dengan Peraturan Gubernur Sulawesi Tenggara Nomor 32 Tahun 2020 tentang Penerapan Disiplin dan Penegakan Hukum Protokol Kesehatan dalam Upaya Pencegahan dan Pengendalian Corona Virus Disease 2019. Sementara di Kabupaten Konawe, untuk mengatasi dan menangani meluasnya COVID-19, dikeluarkanlah Peraturan Bupati Kabupaten Konawe 37 Tahun 2020 tentang Penerapan Disiplin dan Penegakan Hukum Protokol Kesehatan sebagai Upaya Pencegahan dan Pengendalian COVID-2019 dalam Tatanan Kehidupan Era Barua.

Terkait penerapan disiplin dan penegakan hukum protokol kesehatan di beberapa daerah, akhir-akhir menjadi perbincangan yang hangat salah satunya yaitu di lokasi wisata khususnya wisata pantai. Dimana banyak ditemukan para pengunjung wisata pantai tidak mematuhi protokol kesehatan ketika berada di lokasi wisata.

Berangkat dari hal tersebut, dalam upaya penyelenggaraan kepariwisataan dengan di tengah pandemi COVID-19, pemerintah mengeluarkan kebijakan melalui Keputusan Menteri Kesehatan Republik Indonesia Nomor HK.01.07/MENKES/382/2020 tentang Protokol Kesehatan bagi Masyarakat di Tempat dan Fasilitas Umum dalam Rangka Pencegahan dan Pengendalian Corona Virus Disease 2019 (COVID-19) dan terfokus pada penerapan kebersihan, kesehatan, keamanan dan keberlanjutan lingkungan pada destinasi-destinasi pariwisata di Indonesia. Selain itu juga, pemerintah dalam rangka mengantisipasi lonjakan wisatawan pada masa pandemi COVID19, melalui Kementerian Kepariwisataan dan Ekonomi Kreatif menyiapkan program CHSE yang mengacu pada protokol kesehatan yang meliputi 
Cleanliness (Kebersihan), Healty (Kesehatan) dan Environment Sustainability, yang dilengkapi dengan pedoman-pedoman penyelenggaraan CHSE dan diterapkan pada 9 bidang pariwisata dan ekonomi kreatif, yaitu daya tarik wisata, home stay/pondok wisata, hotel, panduan MICE, penyelenggaraan kegiatan event, restoran/rumah makan, wisata arung jeram, wisata golf, dan wisata selam. Namun, persoalan yang muncul kemudian adalah pedoman penyelenggaraan CHSE tersebut tidak dibarengi dengan aturan turunannya sehingga dalam penyelenggaraannya tidak terdapat pengawasan ataupun sanksi penyelenggara kepariwisataan tersertifikasi dan yang tidak melaksanakan CHSE. Dengan kata lain, Pedoman CHSE yang berlaku saat ini masih belum cukup memiliki kekuatan di masyarakat untuk dapat dipatuhi, sehingga pedoman CHSE memerlukan dasar hukum pelaksanaan agar dapat ditaati dan memberikan manfaat dalam penyelenggaraan kepariwisataan, khususnya di lokasi wisata.

Hal ini pula terjadi di lokasi wisata Pantai Toronipa Kabupaten Konawe. Banyak pengunjung Pantai Toronipa yang tidak melaksanakan protokol kesehatan ketika berada di lokasi wisata. Sampai saat ini, belum ada regulasi yang mengatur secara khusus terkait pelaksanaan dan penegakan hukum protokol bagi para pengunjung maupun para pengusaha di lokasi wisata khususnya Pantai Toronipa. Hal ini tentu, apabila dibiarkan begitu saja akan menjadi tempat penyebaran dan penularan COVID-19 yang pada akhirnya akan menimbulkan peningkatan kasus positif dan akan menjadi klaster baru dalam penyebaran COVID-19 di Sulawesi Tenggara, khususnya di Kabupaten Konawe. Untuk itu, pemerintah Provinsi Sulawesi Tenggara, khususnya Kabupaten Konawe bersama masyarakat harus duduk bersama untuk membahas persoalan ini. Langkah yang dapat dilakukan misalnya membentuk peraturan tentang pelaksanaan dan penegakkan hukum protokol kesehatan di lokasi wisata. dimana dalam pelaksanaannya dapat dilakukan dengan cara sosialisasi pelaksanaan protokol kesehatan yang berbasis kearifan lokal maupun membuat narasi-narasi, simbol atau gambar yang berisi nasehatnasehat yang mengandung nilai-nilai kearifan lokal.

\section{B. Penguatan Nilai-nilai Budaya Lokal Melalui Pembentukan Komunitas Masyarakat Berbasis Budaya dalam Rangkah Mencegah Penularan COVID-19 di Pantai Toronipa}

Pandemi COVID-19 telah menyebabkan terjadinya krisis global IMF memprediksi output ekonomi dunia akan menyusut hampir 5\% atau hampir 2\% lebih buruk dari perkiraan yang dirilis pada bulan April. Secara Nasional, pertumbuhan ekonomi Indonesia pada kuartal pertama ditahun 2020 yang biasanya berada pada angka 5 persen, kini turun pada angka 2,97 persen. Di Indonesia penurunan perekonomian salah satunya karena anjloknya pariwisata. 
Hal ini tentu saja tidak dapat dibiarkan berlarut-larut, untuk itu perlu dilakukan konstruksi norma dalam menyongsong new normal di bidang pariwisata. Dalam mengonstruksikan kebijakan new normal tersebut harus menekankan pada Konsep Community Based Tourism. ${ }^{10}$ Konsep Community Based Tourism muncul bermula atas kritik pengelolaan pariwisata yang dilakukan dan dipandang kurang mampu melibatkan masyarakat.

Berdasarkan definisi ASEAN tersebut setidaknya terdapat 10 prinsip CBT yaitu: ${ }^{11}$

1. Melibatkan dan memberdayakan masyarakat untuk memastikan kepemilikan dan transparansi manajemen.

2. Membangun kemitraan dengan pemangku kepentingan yang relevan,

3. Mendapatkan pengakuan

4. Meningkatkan kesejahteraan sosial dan pemeliharaan martabat manusia,

5. Mekanisme berbagi manfaat yang adil dan transparan,

6. Meningkatkan hubungan ekonomi lokal dan daerah,

7. Menghormati budaya dan tradisi lokal,

8. Berkontribusi terhadap konservasi sumber daya alam,

9. Meningkatkan kualitas pengalaman pengunjung dengan memperkuat interaksi antara masyarakat lokal dan wisatawan.

10. Bekerja menuju kemapanan finansial.

Penerapan konsep Community Based Tourism sangat efektif meningkatkan perekonomian masyarakat yang kini menurun karena dengan penerapan konsep Community Based Tourism masyarakat memiliki kontak langsung dengan wisatawan. Michel Picard berpendapat bahwa terdapat perbedaan mencolok yang tidak dapat disangkal antara mereka yang memiliki akses langsung dan tidak dengan uang wisatawan. Masyarakat yang memiliki akses langsung dengan wisatawan memiliki kesempatan lebih baik dan cepat dalam mengembangkan perekonomian dan potensi yang mereka miliki. ${ }^{12}$

Partisipasi masyarakat merupakan komponen terpenting dalam upaya pemulihan ekonomi masyarakat melalui pariwisata. Pengabaian partisipasi masyarakat dalam pengembangan pariwisata juga merupakan awal dari kegagalan pengembangan pariwisata serta kegagalan dalam mencapai tujuan kepariwisataan, sebagaimana disebutkan Pasal 4 Undang-Undang No.10 Tahun 2009 tentang Kepariwisataan yaitu untuk meningkatkan pertumbuhan

10 A.A. Istri Eka Krisna Yanti, "Community Based Tourism Dalam Menyongsong New Normal Desa Wisata Bali," Jurnal Komunikasi Hukum (JKH) 7, no. 1 (2021): 82, https://doi.org/10.23887/jkh.v7i1.31458. Wisata Bali."

11 Eka Krisna Yanti, "Community Based Tourism Dalam Menyongsong New Normal Desa 12 Ibid. 
ekonomi, meningkatkan kesejahteraan rakyat menghapus kemiskinan dan mengatasi pengangguran. ${ }^{13}$

Untuk itu, dalam rangka pengembangan pariwisata di tengah pandemi COVID-19 saat ini, partisipasi masyarakat sangat dibutuhkan khususnya masyarakat di lokasi wisata. Diharapkan melalui partisipasi masyarakat di lokasi wisata dapat mencegah dan menekan penyebaran COVID-19 di lokasi wisata. Mengingat kepadatan pengujung di tempat wisata semakin hari semakin ramai. Dan masih banyak wisatawan yang tidak mematuhi kebijakan protokol kesehatan seperti menjaga jarak dan menggunakan masker, khususnya selama berada di lokasi wisata.

Kondisi ini menjadi kekhawatiran masyarakat Kelurahan Toronipa. Melihat banyaknya kerumunan pengunjung di lokasi wisata Pantai Toronipa yang tidak memperhatikan kebijakan protokol kesehatan, dikhawatirkan akan berpotensi menjadi klaster baru penyebaran COVID-19 di lokasi wisata dan pada akhirnya akan menyebar di lingkungan masyarakat sekitar lokasi wisata Pantai Toronipa.

Berangkat dari kondisi tersebut, maka perlu adanya upaya yang harus dilakukan guna menumbuhkan dan meningkatkan kesadaran atas kebijakan protokol kesehatan oleh pengunjung maupun partisipasi masyarakat setempat guna mencegah penyebaran COVID-19 di lokasi wisata. Salah satu jalan yang bisa ditempuh mengingat belum ada peraturan yang mengatur secara khusus tentang pelaksanaan protokol kesehatan di lokasi wisata untuk mengantisipasi kondisi tersebut adalah dengan membentuk komunitas masyarakat peduli wisata atau relawan COVID-19 di lokasi wisata pantai. Dimana dengan adanya komunitas ini diharapkan dapat memberikan pemahaman terhadap para pengunjung, pelaku usaha maupun warga di lokasi wisata Pantai Toronipa sehingga diharapkan dapat meningkatkan kecerdasan dan pemahaman hukum tentang kebijakan protokol kesehatan melalui pendidikan hukum khususnya pendidikan hukum melalui penguatan nilai-nilai budaya khususnya nilai-nilai kearifan lokal.

Secara konseptual kearifan lokal adalah kecendekiaan budaya yang dimiliki setiap masyarakat beradab yang syarat dengan nilai-nilai kesantunan, kehormatan, kemartabatan, dan kebudayaan manusia. Kearifan lokal sangat penting sebagai sumber pengetahuan dalam pembelajaran dan pendidikan. ${ }^{14}$ Di tengah pandemi COVID-19 saat ini, nilai-nilai luhur kearifan lokal

13 Ibid.

14 Aswati M., Aslim Aslim, and Sarman Sarman, "Sosialisasi Dan Edukasi Masyarakat Melalui Kearifan Lokal Sebagai Upaya Penanganan COVID-19 Di Kelurahan Kampung Salo Kecamatan Kendari Kota Kendari Sulawesi Tenggara," Jurnal Idea of History 3, no. 2 (2020): 38. 
masyarakat setempat dapat dikolaborasikan guna mencegah penyebaran COVID-19 di lokasi wisata Pantai Toronipa.

Nilai-nilai yang ada dalam kearifan lokal merupakan nilai-nilai luhur yang berlaku dalam tata kehidupan masyarakat, antara lain untuk melindungi dan mengelola lingkungan secara lestari bagi kehidupan masyarakat sehingga dapat terjaga dengan baik. Kearifan lokal bukan sekedar nilai tradisi atau ciri lokalitas semata melainkan nilai tradisi yang mempunyai daya guna untuk mewujudkan harapan atau nilai-nilai kemapanan yang juga secara universal yang didambakan oleh manusia terlebih saat pandemi sekarang, dimana kearifan lokal sangat penting karena dalam prinsip sebuah kearifan lokal salah satunya adalah kebersamaan yang merupakan jantung utama sebuah budaya dalam masyarakat dapat berjalan dengan baik. Untuk kondisi saat ini yaitu adaptasi kebiasaan baru, masyarakat perlu diedukasi secara persuasif dengan pendekatan nilai kearifan lokal. ${ }^{15}$ Pendekatan ini mengajak masyarakat untuk berpikir tentang kondisi yang terjadi saat ini. Peduli terhadap lingkungan, disiplin pada diri sendiri, berempati serta bersama mencari solusi permasalahan dengan mengikuti aturan yang telah ditetapkan pemerintah berupa protokol kesehatan yang menjamin kehidupan bersama bersifat adil, gotong royong dan orientasi terhadap kemajuan untuk penyelesaian masalah pandemi ini. ${ }^{16}$

Dalam kondisi adaptasi kebiasaan baru ini masyarakat diminta untuk dapat hidup berdampingan dengan COVID-19 dengan disiplin. Masyarakat harus disiplin menerapkan protokol kesehatan dengan melihat indikator Perilaku Hidup Bersih dan Sehat (PHBS) dalam berbagai tatanan kehidupan yaitu kebiasaan CTPS: menggunakan masker; tidak merokok; melakukan aktivitas fisik; tidak meludah sembarangan; melakukan etika batuk dan bersin; menjaga jarak; berjemur di pagi hari; mandi setelah beraktivitas di luar rumah; mengonsumsi buah dan sayur; memasak makanan sampai matang, menggunakan air bersih; menggunakan jamban sehat; membuang sampah pada tempatnya dan menjaga kebersihan diri dan lingkungan. Konsistensi dalam diri masyarakatlah yang diharapkan untuk melakukan perubahan menjadi budanya dan perilaku yang bersih dan sehat agar pandemi ini segera berlalu. ${ }^{17}$

15 M., Aslim, and Sarman, "Sosialisasi Dan Edukasi Masyarakat Melalui Kearifan Lokal Sebagai Upaya Penanganan COVID-19 Di Kelurahan Kampung Salo Kecamatan Kendari Kota Kendari Sulawesi Tenggara."

${ }^{16}$ Ibid.

17 Ibid. 


\section{Penguatan Nilai-nilai Budaya Lokal Melalui Pembentukan Komunitas Masyarakat Berbasis Budaya dalam Rangkah Mencegah Penularan COVID-19 di Pantai Toronipa}

Di Sulawesi Tenggara sendiri terdapat beberapa suku/etnik yang mendiami wilayah Sulawesi Tenggara di antaranya yaitu suku Muna, Tolaki, dan Bajo. Dengan adanya suku/etnik tersebut, maka dipastikan bahwa begitu beragam warisan nilai (kearifan lokal) masyarakat yang mengandung agenda pendidikan dalam berbagai aspek kehidupan. Dalam rangka mencegah penyebaran COVID-19, terdapat beberapa nilai kearifan lokal yang digunakan atau diaplikasikan masyarakat dalam mencegah penyebaran COVID-19 di lokasi wisata Pantai Toronipa di antaranya sebagai berikut:

1. Nilai kearifan lokal Suku Muna

Suku Muna memiliki banyak kearifan yang memiliki unsur nasehat dan pendidikan. Nilai tersebut tidak hanya menjadi konsep pengetahuan dan nilai semata, akan tetapi cukup banyak menjadi landasan perilaku. Adapun nilainilai kearifan lokal yang dapat digunakan dalam mencegah penyebaran COVID-19 di lokasi wisata Pantai Toronipa yaitu: ${ }^{18}$

a. Katangari (nasehat).

Dalam bahasa Muna mengandung muatan nasehat dan pesan yang memiliki fungsi dan makna bagi kehidupan masyarakat. Setiap generasi pada suku ini pasti mendapatkan proses katangari (nasehat) baik secara formal maupun informal. Formal dalam artian budaya melalui ritual khusus sesuai siklus hidup manusia. Menurut tokoh Muna, La Waweha, sejak dalam perut ibunya bagi orang Muna sudah harus diberikan nasehat-nasehat. Memberikan perlakuan khusus dan bisikan pada bayi yang masih berada dalam kandungan. Selanjutnya saat lahir dan saat anak tersebut diakikah. Proses sunat/khitan bagi anak baik laki-laki maupun perempuan wajib diberikan "toba" yaitu suatu substansi nasehat untuk merefleksikan hakikat dirinya sebagai manusia dan tujuan hidupnya. Hal lain yang diberikan dalam toba ini adalah prinsip-prinsip dalam bersikap dan bertutur kata baik pada sanga pencipta, pada kedua orang tua, pada saudara yang lebih tua, pada saudara yang lebih muda, bahkan pada sesama makhluk yang lain.

Melalui Nilai luhur yang terkandung dalam katangari tersebut, masyarakat Pantai Toronipa atau para pengunjung Pantai Toronipa dapat saling menasihati pentingnya menerapkan protokol kesehatan dengan cara

18 Pendais Hak, "Etnopedagogik Pada Masyarakat Suku Muna, Tolaki, Dan Bajo Di Sulawesi Tenggara (Strategi Pengintegrasian Kearifan Lokal Dalam Pembelajaran Sejarah Untuk Penguatan Karakter Siswa)," in Seminar Nasional Sejarah Ke 4 Jurusan Pendidikan Sejarah Universitas Negeri Padang (Padang: Universitas Negeri Padang, 2019), 286-87. 
memberikan nasehat untuk hakikat menjaga kesehatan diri sendiri dan orang lain serta manfaatnya, bahkan merefleksikan hakikat dirinya sebagai manusia dan tujuan hidupnya. Dengan demikian, akan tumbuh rasa sadar akan pentingnya mematuhi protokol kesehatan dalam rangka mencegah penyebaran COVID-19 di lokasi wisata Pantai Toronipa demi kesehatan diri sendiri dan kesehatan bersama serta kenyamanan bersama.

b. Falia (Pantangan).

Sama dengan suku lainya, setiap kelompok masyarakat ada pantangannya. Tetapi bagi orang Muna, falia suatu tata nilai yang dibuat untuk mengaja tubuh/fisik manusia, menjaga hubungan sosial manusia, menjaga perilaku, menjaga tutur kata dan sebagainya yang dilengkapi dengan rumor akibat/dampak jika falia tersebut dilanggar. Jaman dulu orang Muna sangat memegang teguh konsep falia ini. Takut melanggarnya karena akan berdampak buru bagi dirinya.

Dalam rangka mencegah penularan COVID-19 di lokasi Pantai Toronipa, nilai-nilai falia dapat diterapkan dengan melakukan tulisan-tulisan atau narasi-narasi yang berisi pesan falia (pantangan) berperilaku melanggar protokol kesehatan di lokasi wisata Pantai Toronipa. Misalnya, membuat tulisan-tulisan atau narasi-narasi di sekitar pantai bahwa falia batuk di hadapan orang lain tanpa menutup mulut, falia buang ingus sembarangan di lokasi pantai dan lain sebagainya.

\section{c. Pokadulu}

Istilah pokadulu dapat dimaknai dengan gotong royong. Pokadulu dilakukan dengan tujuan agar dalam setiap pekerjaan tidak terlalu berat, menguji kesetiaan dan kepedulian teman atau tetangga, dan adanya tenggang rasa dalam kehidupan mereka. Pokadulu sudah menjadi kebiasaan masyarakat Muna sejak masa kerajaan. Beberapa pekerjaan yang dilakukan dengan cara pokadulu misalnya pekerjaan "degalu” yaitu berkebun mulai membuka lahan sampai panen, bidang sosial seperti pokadulu membangun rumah, pindah rumah, membangun bantea (tenda) untuk perkawinan dan acara-acara lainnya.

Nilai pokadulu dapat terapkan dalam upaya mencegah penularan COVID-19 di lokasi Pantai Toronipa, misalnya dengan membentuk satuan tugas gotong royong pencegahan penyebaran COVID-19 di lokasi wisata Pantai Toronipa. Penerapan nilai Pokadulu misalnya dapat dilakukan dengan mengumpulkan donasi secara sukarela untuk keperluan pembelian masker untuk para pengujung wisata Pantai Toronipa, menyediakan tempat cuci tangan, membuat tulisan-tulisan atau narasi yang berisi bahwa, "pogadulu menjaga lokasi wisata Pantai Toronipa dari penyebaran COVID-19".

2. Nilai kearifan lokal Suku Tolaki 
Tolaki adalah salah satu suku yang cukup banyak popularitasnya di Sulawesi Tenggara, mendiami wilayah daratan dan tersebar pada 4 kabupaten di Sulawesi Tenggara seperti Konawe, Konawe Utara, Konawe Selatan, dan Kota Kendari. Memiliki warisan ragam budaya dan kearifan yang patut selalu direvitalisasi sebagai menjaga identitas dan jati diri etnik ini. Adapun nilai-nilai kearifan lokal Suku Tolaki yang dapat digunakan dalam menanggulangi penyebaran COVID-19 di lokasi wisata Pantai Toronipa yaitu: ${ }^{19}$

\section{a. Samaturu.}

Samaturu, dapat dimaknai dengan saling menopang, saling memberi, dan saling menjaga. Bagi Tolaki, budaya ini untuk memuliakan dan mengutamakan hidup untuk saling menjalin persatuan, suka menolong orang lain yang sedang membutuhkan pertolongan. Samaturu juga merupakan bentuk kepekaan dan kepedulian sosial. Tradisi samaturu bukanlah sekedar slogan saja, akan tetapi mengandung ranah afektif (sikap) dan psikomotorik (praktik kebersamaan) yang syarat dengan tanggung jawab sesama. Jika membantu orang dengan asalasalan maka itu tetap dikategorikan sebagai orang yang belum menjalankan budaya samaturu dengan baik dan tanggung jawab. ${ }^{20}$

Melalui nilai-nilai luhur yang terdapat dalam samuturu dapat dikolaborasikan dengan pelaksanaan protokol kesehatan di lokasi wisata Pantai Toronipa guna mencegah penyebaran COVID-19 di lokasi Pantai Toronipa, misalnya dengan membuat narasi bahwa "Memakai masker, mencuci tangan dan tidak berkerumun di lokasi pantai bagian dari saling menjaga antar sesama manusia (samaturu)", dan seterusnya.

\section{b. Kohanu.}

Kohanu, sering disebut dengan budaya malu. Nilai kearifan ini merupakan sistim pertahanan moral bagi diri sendiri, misalnya ada orang yang dikatakan malas bekerja maka pihak yang dijadikan sasaran klaim tersebut akan merasa malu dan memotivasi diri untuk berubah lebih tekun dan rajin. Orang akan selalu menjaga dirinya dari stigma pemalas, atau stigma lainnya yang bermakna tidak baik, hal ini karena setiap orang Tolaki harus merasa kohanu atau malu. Dalam kegiatan pendidikan siswa akan merasa malu jika tidak menyelesaikan tugas dengan baik, dia dianggap pemalas dan tidak tanggung jawab. Maka nilai-nilai kohanu harus selalu ditumbuhkan termasuk dalam proses pembelajaran. Pada pembelajaran sejarah lokal bahkan sejarah sosial, orang Tolaki dikenal dengan kegarangan dalam mempertahankan harga

19 Hak, "Etnopedagogik Pada Masyarakat Suku Muna, Tolaki, Dan Bajo Di Sulawesi Tenggara (Strategi Pengintegrasian Kearifan Lokal Dalam Pembelajaran Sejarah Untuk Penguatan Karakter Siswa)."

20 Ibid. 
dirinya karena pada diri mereka melekat nilai kohanu. Kondisi ini memiliki norma yang sama dengan suku Bugis-Makassar.

Nilai-nilai luhur kohanu yang bisa digunakan dalam upaya mencegah penyebaran dan penularan COVID-19 di lokasi wisata Pantai Toronipa, misalnya dengan membuat narasi-narasi seperti "memalukan ketika datang di pantai tidak memakai masker (pesan dari kohanu)".

3. Nilai Kearifan Lokal Suku Bajo

a. Bapongka

Bapongka yaitu sebuah tradisi melaut yang ramah terhadap alam. Istilah bapongka disebut juga dengan babangi adalah bermalam di laut selama 3 hari sampai sebulan. Pongka adalah berlayar mencari nafkah atau hasil-hasil laut ke daerah atau provinsi lain, selama beberapa minggu/bulan. Menangkap Hasil Laut bapongka adalah suatu kegiatan melaut khas masyarakat Bajo atau Bajau di Pulau Saponda yang telah dilakukan sejak lama. Mereka pergi ke satu tempat di luar kampungnya untuk mencari hasil laut selang berhari-hari hingga berminggu-minggu secara berkelompok. Setiap kelompok terdiri dari tiga sampai lima perahu, masing-masing perahu terdapat satu orang. Pembentukan kelompok kecil bapongka lebih sering dilakukan berdasarkan kedekatan hubungan. Biasanya kelompok kecil tersebut akan bertemu dengan kelompok kecil yang lain di suatu lokasi penangkapan dan akhirnya membentuk kelompok besar yang jumlahnya bisa mencapai 15 bahkan 20 perahu. Kelompok bapongka berupaya menangkap ikan, udang, lola, atau kepiting, teripang. Mereka melakukan penangkapan secara bergerombol dan saling membantu bukan saling bersaing. Selanjutnya hasil dari tangkapan mereka dipasarkan langsung pada Pasar Ikan Pelelangan Kota Kendari yang telah berlangsung sejak masa penjajahan Belanda. ${ }^{21}$

Nilai-nilai luhur dari bapongka yang dapat diaplikasikan dalam rangka mencegah penyebaran COVID-19 di lokasi wisata Pantai Toronipa misalnya dengan membentuk kelompok kecil dalam sebagai relawan COVID-19 di lokasi wisata. memberikan pemahaman terhadap para pengunjung, pelaku usaha maupun warga di lokasi wisata Pantai Toronipa sehingga di harapkan dapat meningkatkan kecerdasan dan pemahaman hukum tentang kebijakan protokol kesehatan melalui pendidikan hukum khususnya pendidikan hukum melalui penguatan nilai-nilai budaya khususnya nilai-nilai kearifan lokal. Dengan kelompok kecil yang dibentuk diharapkan dapat menggerakkan

${ }^{21}$ Pendais Hak, "Kajian Pemberdayaan Pendidikan Masyarakat Etnik Bajo Berbasis Kearifan Lokal (Studi Di Pulau Saponda Kecamatan Soropia Kabupaten Konawe)," in Prosiding Seminar Nasional Dan Pra Lokakarya Asosiasi Departemen/Jurusan Antropologi Seluruh Indonesia (ADJASI) (Kendari: Fakultas Ilmu Budaya Universitas Halu Oleo, 2018), 275. 
masyarakat yang lain sehingga akan terbentuk kelompok besar, yang pada akhirnya nilai-nilai luhur dari bapongka terealisasi dengan baik.

b. Pasipupukang

Pasipupukang, yang artinya perkumpulan masyarakat suku Bajo atau tradisi berkumpul masyarakat Bajo untuk mencari solusi dari permasalahanpermasalahan yang mereka hadapi. Pasipupukang ini biasanya dilakukan dengan tata cara misalnya jika terjadi kasus perkelahian di antara sesama masyarakat Bajo, diadakanlah pertemuan di suatu tempat, misalnya di rumah tokoh adat atau di balai pertemuan di Desa. Pertemuan ini dihadiri oleh kedua belah pihak yang berseteru, tokoh adat, tokoh masyarakat, kepala desa. Fungsi pasipupukang di Pulau Saponda juga dijadikan sebagai media kerja sama dan mempersatukan. Bahkan di Pulau Bokori satu kawasan dengan Pulau Saponda, sama-sama masuk dalam Kecamatan Soropia, mereka menjadikan tradisi pasipupukang sebagai bentuk gotong royong dalam menyekolahkan anak-anak Bajo di pulau ini, sehingga sudah ada puluhan anak-anak Bajo yang menamatkan sekolah pada PT (S1). Konsep ini memiliki kesamaan dengan tradisi pokadulu yang dikembangkan masyarakat Muna. Hanya saja pada masyarakat Muna tradisi pokadulu lebih diarahkan pada bentuk-bentuk kerja sama dan gotong royong dalam meringankan beban pekerjaan tertentu, misalnya dalam bertani, acara hajatan pesta perkawinan, memindahkan rumah, dan lain-lain. ${ }^{22}$

Nilai-nilai luhur yang dapat diaplikasikan dari nilai pasipupukang yaitu dengan secara bersama-sama, berkumpul dan berdialog mencari solusi terbaik dari permasalahan yang dihadapi khususnya persoalan banyaknya pengunjung, pelaku usaha dan warga setempat yang tidak mematuhi protokol kesehatan di lokasi wisata Pantai Toronipa. Dengan demikian, melalui kegiatan tersebut akan diperoleh suatu kesepakatan hal-hal yang akan dilakukan dalam mencegah penyebaran COVID-19 di lokasi wisata Pantai Toronipa, baik dengan membentuk komunitas masyarakat untuk menjadi garda terdepan dalam meningkatkan kecerdasan dan pemahaman hukum tentang kebijakan protokol kesehatan melalui pendidikan hukum khususnya pendidikan hukum melalui penguatan nilai-nilai budaya khususnya nilai-nilai kearifan lokal.

\section{Penguatan Integratif, Relasi dan Kebijakan Hukum Berbasis Budaya Lokal}

COVID-19 tidak lagi menjadi bencana nasional tapi juga dianggap sebagai bencana internasional yang telah mampu melumpuhkan peradaban manusia di berbagai sektor. Upaya peningkatan kesiapsiagaan masyarakat telah

${ }^{22}$ Hak, "Kajian Pemberdayaan Pendidikan Masyarakat Etnik Bajo Berbasis Kearifan Lokal (Studi Di Pulau Saponda Kecamatan Soropia Kabupaten Konawe).” 
dilakukan melalui penerapan protokol kesehatan yang ketat dalam kehidupan sosial masyarakat. Namun demikian upaya kesiapsiagaan masyarakat perlu dilaksanakan melalui pendidikan hukum yang berorientasi pada penguatan nilai-nilai budaya lokal yang tidak hanya berbasis komunitas tetapi basis komunitas tersebut harus mampu diintegrasikan di antara kelompok-kelompok masyarakat melalui penguatan struktural yang nantinya akan menciptakan relasi yang kuat bagi masyarakat sebagai ujung tombak pencegahan penyebaran COVID-19.

Penguatan kelembagaan secara integratif baik antara pemerintah, masyarakat maupun swasta merupakan faktor esensial dalam upaya mitigasi bencana COVID-19. Penguatan kelembagaan yang berbasis kearifan lokal dalam bentuk kesiapsiagaan, sistem peringatan dini tentang peningkatan COVID-19 di sektor pariwisata, tindakan darurat oleh komunitas di daerah pariwisata yang bertujuan mewujudkan masyarakat yang berbudaya sehingga meminimalkan dampak yang ditimbulkan oleh COVID-19.

Teori Benjamin Blum menyatakan bahwa pengetahuan atau kognitif merupakan domain yang sangat penting untuk terbentuknya tindakan seseorang. Dalam teori ini mengandung frasa bahwa setiap sikap dan perilaku masyarakat pengunjung Pantai Toronipa merupakan faktor terbesar dalam rangka pencegahan penyebaran COVID-19. Sikap atau perilaku merupakan faktor penentu karena sikap berhubungan dengan persepsi, kepribadian dan motivasi. Sikap pula dapat diartikan sebagai kesiapsiagaan mental yang dipelajari dan diorganisasi melalui pengalaman dan mempunyai pengaruh tertentu atas cara tanggap seseorang terhadap orang lain, terhadap lingkungan pariwisata dan situasi sosial yang berhubungan dengannya melalui pendidikan hukum penguatan nilai-nilai budaya lokal dalam rangka mencegah penyebaran COVID-19 di lokasi pantai wisata Pantai Toronipa akan menumbuhkan sikap integratif di dalam masyarakat yang akan berdampak pada relasi komponen emosional, komponen kognitif berupa persepsi pendapat dan keyakinan dalam berperilaku yang berdasarkan pada penerapan protokol kesehatan secara terstruktur, sistematis dan masif.

Penguatan narasi simbol dan gambar yang mengandung nasihat nilainilai luhur budaya lokal akan mampu mempengaruhi persepsi masyarakat tentang pentingnya penerapan protokol sebelum, saat, sesudah berada di lokasi wisata. dalam rangka upaya penanggulangan penyebaran COVID-19 di lokasi pariwisata yang berbasis komunitas, integratif dan relasi maka perlu dilakukan langkah preventif dalam rangka menjamin keselamatan pengunjung, pelaku usaha dan masyarakat sekitar di lokasi wisata Pantai Toronipa sebagai berikut: 
1. Pembentukan komunitas/desa tangguh bencana

Pembentukan komunitas/desa tangguh yang berfokus pada pencegahan penyebaran COVID-19 melibatkan berbagai masyarakat antar suku yang tergabung dalam satu komunitas. Komunitas tersebut bertugas menyampaikan pesan yang berisi nasihat-nasihat yang bersumber dari nilai-nilai budaya luhur kearifan lokal yang dikolaborasikan dengan ajakan untuk mematuhi protokol kesehatan saat berada di lokasi wisata Pantai Toronipa.

2. Penyuluhan pendidikan hukum yang terkait dengan regulasi pencegahan penyebaran COVID-19.

Pendidikan hukum terkait regulasi pencegahan COVID-19 perlu diketahui oleh komunitas tentang aturan dan sanksi yang dapat diterapkan terhadap pelanggar protokol kesehatan di Pantai Toronipa terutama kaitannya dengan sanksi kurungan dan denda. Beberapa peraturan perundang-undangan yang wajib diketahui oleh komunitas, pengunjung, pelaku usaha dan masyarakat adalah sebagai berikut:

a. Peraturan Pemerintah Pengganti Undang- Undang Nomor 1 Tahun 2020 tentang Kebijakan Keuangan Negara dan Stabilitas Sistem Keuangan untuk Penanganan Pandemi Corona Virus Disease 2019 (COVID-19) dan/atau dalam Rangka Menghadapi Ancaman Yang Membahayakan Perekonomian Nasional dan/atau Stabilitas Sistem Keuangan;

b. Peraturan Pemerintah Nomor 21 Tahun 2020 tentang Pembatasan Sosial Berskala Besar dalam Rangka Percepatan Penanganan Corona Virus Disease 2019 (COVID-19);

c. Keputusan Presiden Nomor 11 Tahun 2020 tentang Penetapan Kedaruratan Kesehatan Masyarakat Corona Virus Disease 2019 (COVID-19);

d. Keputusan Menteri Kesehatan Republik Indonesia No.HK.01.07/MENKES/104/2020 tentang Penetapan Infeksi Novel Corona virus (Infeksi 2019-nCoV);

e. Peraturan Gubernur Sulawesi Tenggara Nomor 32 Tahun 2020 tentang Penerapan Disiplin dan Penegakan Hukum Protokol Kesehatan dalam Upaya Pencegahan dan Pengendalian Corona Virus Disease 2019;

f. Peraturan Bupati Kabupaten Konawe Nomor 37 Tahun 2020 tentang Penerapan Disiplin dan Penegakan Hukum Protokol Kesehatan sebagai Upaya Pencegahan dan Pengendalian COVID-2019 dalam Tatanan Kehidupan Era Baru.

3. Kebijakan peningkatan kapasitas pendidikan hukum melalui nilai-nilai budaya lokal. 
Secara konkret pendidikan hukum melalui penguatan nilai-nilai budaya lokal untuk meningkatkan kapasitas penanggulangan risiko penyebaran COVID-19 di lokasi wisata Pantai Toronipa:

a. membangun pemahaman masyarakat komunitas, pengunjung, dan pelaku usaha mengenai ancaman, kerentanan serta konsekuensi risiko, dampak penyebaran COVID-19;

b. menyiapkan kader-kader lokal yang potensial untuk menggerakkan partisipasi melalui komunitas dalam membangun gerakan pencegahan COVID-19;

c. melakukan pemetaan di Kelurahan Toronipa secara partisipasi terhadap titik-titik kerawanan penyebaran COVID-19;

d. pemanfaatan sumber daya alam melalui penanaman tanaman-tanaman obat tradisional sebagai alternatif pengobatan yang terdampak COVID-19.

Penguatan program komunitas yang integratif dalam rangka penguatan relasi antar masyarakat berdasarkan pada prinsip-prinsip sebagai berikut:

a. prinsip pencegahan COVID-19 adalah tanggung jawab bersama;

b. masyarakat sebagai pelaku utama;

c. pemanfaatan sumber daya lokal;

d. prinsip kemanusiaan;

e. kemitraan.

Melalui pendidikan hukum yang berbasis nilai-nilai budaya lokal dalam rangka pencegahan penyebaran COVID-19 di lokasi wisata Pantai Toronipa diharapkan mampu melahirkan sikap dan perilaku bahwa COVID-19 merupakan bahaya nyata dan bukan isu global yang sengaja disampaikan untuk menciptakan ketakutan masyarakat. Melalui pendidikan hukum pula dapat menciptakan pengetahuan hukum bahwa akibat pelanggaran protokol kesehatan berorientasi pada sanksi baik yang bersifat pidana.

\section{PENUTUP}

Pendidikan hukum melalui penguatan nilai-nilai budaya lokal dalam rangka mencegah penyebaran COVID-19 di lokasi wisata Pantai Toronipa dapat dilakukan dengan cara penguatan regulasi berbasis komunitas integrasi dan relasi. Selanjutnya, Penguatan melalui nilai-nilai budaya lokal dapat dilakukan melalui penguatan kelembagaan secara integratif baik antara pemerintah, masyarakat maupun swasta merupakan faktor esensial dalam upaya mitigasi bencana COVID-19. Penguatan kelembagaan yang berbasis kearifan lokal dalam bentuk kesiapsiagaan, sistem peringatan dini tentang peningkatan COVID-19 di sektor pariwisata, tindakan darurat oleh komunitas di daerah pariwisata yang bertujuan mewujudkan masyarakat yang berbudaya sehingga meminimalkan dampak yang ditimbulkan oleh COVID-19. Selain itu juga, Penguatan narasi simbol dan gambar yang mengandung nasihat nilai-nilai 
luhur budaya lokal akan mampu mempengaruhi persepsi masyarakat tentang pentingnya penerapan protokol sebelum, saat, sesudah berada di lokasi wisata. Dimana, upaya penanggulangan penyebaran COVID-19 di lokasi pariwisata yang berbasis komunitas, integratif dan relasi dapat dilakukan langkah preventif dalam rangka menjamin keselamatan pengunjung, pelaku usaha dan masyarakat sekitar di lokasi wisata Pantai Toronipa seperti melakukan pembentukan komunitas/desa tangguh bencana, penyuluhan pendidikan hukum yang terkait dengan regulasi pencegahan penyebaran COVID-19 dan melalui kebijakan peningkatan kapasitas pendidikan hukum melalui nilai-nilai budaya lokal.

\section{DAFTAR PUSTAKA}

Eka Krisna Yanti, A.A. Istri. "Community Based Tourism Dalam Menyongsong New Normal Desa Wisata Bali." Jurnal Komunikasi $\begin{array}{llllll}\text { Hukum } \quad(J K H) & 7, & \text { no. } & 1 & \text { (2021): } & 72-86 .\end{array}$ https://doi.org/10.23887/jkh.v7i1.31458.

Euis Kurniati, Dina Kusumanita Nur Alfaeni, Fitri Andriani. "Analisis Peran Orang Tua Dalam Mendampingi Anak Di Masa Pandemi Covid-19." Jurnal Obsesi : Jurnal Pendidikan Anak Usia Dini 5, no. 1 (2021): 421.

Hak, Pendais. "Etnopedagogik Pada Masyarakat Suku Muna, Tolaki, Dan Bajo Di Sulawesi Tenggara (Strategi Pengintegrasian Kearifan Lokal Dalam Pembelajaran Sejarah Untuk Penguatan Karakter Siswa).” In Seminar Nasional Sejarah Ke 4 Jurusan Pendidikan Sejarah Universitas Negeri Padang, 279-96. Padang: Universitas Negeri Padang, 2019.

_ . "Kajian Pemberdayaan Pendidikan Masyarakat Etnik Bajo Berbasis Kearifan Lokal (Studi Di Pulau Saponda Kecamatan Soropia Kabupaten Konawe)." In Prosiding Seminar Nasional Dan Pra Lokakarya Asosiasi Departemen/Jurusan Antropologi Seluruh Indonesia (ADJASI), 270-86. Kendari: Fakultas Ilmu Budaya Universitas Halu Oleo, 2018.

Lenterasultra, Redaksi. "Ribuan Pengunjung Padati Pantai Toronipa." Lentera Sultra, 2020.

M., Aswati, Aslim Aslim, and Sarman Sarman. "Sosialisasi Dan Edukasi Masyarakat Melalui Kearifan Lokal Sebagai Upaya Penanganan COVID-19 Di Kelurahan Kampung Salo Kecamatan Kendari Kota Kendari Sulawesi Tenggara." Jurnal Idea of History 3, no. 2 (2020): 3143.

Nafrin, Irinna Aulia, and Hudaidah. "Perkembangan Pendidikan Indonesia Di Masa Pandemi Covid-19.” Edukatif: Jurnal Ilmu Pendidikan 3, no. 2 (2021): 456-62.

Senong, Abdul Azis. "Pantai Toronipa Konawe Dikunjungi Ribuan Wisatawan.” Antara Sultra, 2020.

Sherly Adam, Reimon Supusepa, Jacob Hattu, Iqbal Taufik. "Penegakan Hukum Terhadap Pelanggaran Protokol Kesehatan Yang Dilakukan Masyarakat Pada Masa Pandemi Covid-19 Di Kota Ambon." SASI 27, 
p-ISSN : 2541-2345, e-ISSN : 2580-8842

no. 2 (2021): 230-46.

Sudikno Mertokusumo. Meningkatkan Kesadaran Hukum Masyarakat. 1st ed. Yogyakarta: Liberty, 1981.

Yunus (Editor), Irwansyah and Ahsan. Penelitian Hukum, Pilihan Metode \& Praktik Penulisan Artikel. Yogyakarta, Indonesia: Mirra Buana Media, 2020. 